\title{
Entrepreneurial Intention of University Graduates of Bangladesh: Looking for New Economic Opportunities
}

\author{
Moumita Karmoker ${ }^{1}$, Md. Uzzal Mia ${ }^{1}$, Rumana Biswas ${ }^{2}$, Md. Julhaz Hossain ${ }^{3}$, Mst. Anjuman Ara ${ }^{1}$, \\ Md. Abdul Alim ${ }^{1, *}$ \\ ${ }^{1}$ Department of Marketing, University of Rajshahi, Bangladesh \\ ${ }^{2}$ Department of Agricultural Economics, Sher-e-Bangla Agricultural University, Bangladesh \\ ${ }^{3}$ Institute of Business Administration, University of Rajshahi, Bangladesh
}

Received July 24, 2020; Revised September 21, 2020; Accepted October 19, 2020

\section{Cite This Paper in the following Citation Styles}

(a): [1] Moumita Karmoker, Md. Uzzal Mia, Rumana Biswas, Md. Julhaz Hossain, Mst. Anjuman Ara, Md. Abdul Alim, "Entrepreneurial Intention of University Graduates of Bangladesh: Looking for New Economic Opportunities, " Advances in Economics and Business, Vol. 8, No. 6, pp. 311 - 320, 2020. DOI: 10.13189/aeb.2020.080601.

(b): Moumita Karmoker, Md. Uzzal Mia, Rumana Biswas, Md. Julhaz Hossain, Mst. Anjuman Ara, Md. Abdul Alim (2020). Entrepreneurial Intention of University Graduates of Bangladesh: Looking for New Economic Opportunities. Advances in Economics and Business, 8(6), 311 - 320. DOI: 10.13189/aeb.2020.080601.

Copyright $\odot 2020$ by authors, all rights reserved. Authors agree that this article remains permanently open access under the terms of the Creative Commons Attribution License 4.0 International License

\begin{abstract}
The transition from education to work is a crucial challenge for several young people in many countries. University graduates and other recently graduated people mainly face this challenge that leads to extreme unemployment. This indicates that a growing number of graduates fail to find their expected jobs around the globe. This study attempts to investigate the entrepreneurial intention of university graduates in the context of Bangladesh. The conceptual framework of this study was developed based on the Theory of Planned Behavior (TPB) and surveyed 235 university graduates. The collected data were analyzed by using Partial Least Squares-based Structural Equation Modeling (PLS-SEM). The findings of this study clearly demonstrate that career adaptability, risk-taking propensity, and institutional learning play a significantly positive role in developing the entrepreneurial self-efficacy of university graduates. The overall entrepreneurial self-efficacy of the graduates strongly influences their entrepreneurial intention. The study presents notable theoretical and practical implications that can be useful for policy-makers, higher educational institutions, and the Bangladeshi government as a course of action. Finally, conclusions, limitations, and future research directions are outlined.
\end{abstract}

$\begin{array}{lrcr}\text { Keywords } & \text { Career } & \text { Adaptability, } & \text { Risk-taking } \\ \text { Propensity, } & \text { Institutional } & \text { Learning, } & \text { Self-efficacy, }\end{array}$
Entrepreneurial Intention, Bangladesh

\section{Introduction}

The transition from education to work is a crucial challenge for numerous young people in many countries [16]. It is more difficult for university graduates and other recently graduated people because the transition may lead to extreme unemployment [10]. This indicates that a growing number of graduates fail to find their expected jobs around the globe. However, entrepreneurship is considered as an instrument for economic growth and national development [25]. It creates employment opportunities, generates revenues, and ensures wealth creation for the nation [1]. University graduates and other recently graduated people who wish to start new businesses are the most potent group engaged in entrepreneurial activities [30]. The process of entrepreneurial activities begins with the entrepreneurial intention of an individual [50]. Entrepreneurial intention is a state of mind that directs the attention, experience, and action of an individual towards a particular goal. It is the foremost interpreter of a person's behaviour that may inspire them to be entrepreneurs [48].

Many developing countries have been struggling to 
handle the consequences of the unemployment problem [7, 48]. Bangladesh is not exceptional with this. It is crucial to change the mind-set of university graduates into an alternative employment option as employability is the primary concern to them [52]. Hence, entrepreneurship can be an ideal mechanism to overcome this situation as it provides many people with economic activity in society [37]. Although the graduates of few disciplines have focused on entrepreneurial activities, it is less observed in recent years, especially after the revised salary structure of the Bangladesh government in 2015. The university graduates think that it is more reasonable for them to choose government jobs by avoiding their interests in entrepreneurship, considering the risks and benefits.

In relation to the above, the drivers that lead the entrepreneurial intention of university graduates can be an essential research topic. The constructs of knowledge, experience, perceived behavioral control, and personality traits have been considered in many previous studies in entrepreneurial intention literature [44]. However, the constructs of career adaptability, risk-taking propensity, institutional learning, and self-efficacy have not been considered much $[10,71]$. Thus, this study addresses these constructs to examine the entrepreneurial intention of university graduates in the context of a developing country such as Bangladesh. More specifically, it aims to assess how career adaptability, risk-taking propensity, institutional learning, and self-efficacy influence university graduates' entrepreneurial intention. Researchers have also documented that many people intend to be entrepreneurs from a relatively younger age [59], making the university graduates a significant group prone to systematic study. The findings can provide the policy-makers as well as universities that are committed to an entrepreneurial culture with useful strategies and directions.

The rest of the paper first provides the theoretical lens as the foundation of this study, followed by reviews of the extant literature, including conceptual framework and hypotheses development. Next, it explains research methods and findings. Lastly, the results and the implications for both theory and practice are discussed, followed by conclusions, limitations, and future research directions.

\section{Literature Review}

\subsection{Theory of Planned Behavior (TPB)}

This widespread concept of the theory of planned behavior (TPB) was employed as the basis of this study. Ajzen proposed the TPB in 1988, an extension of the idea of reasoned action (TRA) with the inclusion of perceived behavioral control. Attitude, subjective norms, and perceived behavioral control are the three basic elements of this theory that help to predict behaviors that are not under complete volitional control [5]. The idea mainly proposes that people are likely to show a particular type of behavior if they believe that such behavior will lead to a specific outcome, and their essential referents (friends, family members, etc.) will find value in it, and they support the behavior. It is also important that people have the required abilities, resources, and opportunities to actualize behavior [4]. TPB reflects the attitudes and perceived possibilities that are essential to carry out a particular behavior [5]. This can be further highlighted that behavioral intention is considered as one of the most important predictors of behavior. The behavioral intention is determined by attitude (positive or negative evaluation of an individual), subjective or social norms (social pressure), and perceived behavioral control (the perception of a person or actor). Thus, a more positive attitude, strong subjective norm, and greater perceived behavioral control can strengthen a person's intention to perform the behavior of his/her interest [5].

Entrepreneurship development as planned and projected activities, maintains the systematic steps while entrepreneurial intention occupies one of its essential layers $[38,46]$. Previous studies on positive or negative influential determinants of entrepreneurial intentions are hardly found [19]. Hence, it is a timely effort to undertake studies on affecting variables of entrepreneurial intentions [69]. Therefore, career adaptability, risk-taking propensity, institutional learning, and self-efficacy are considered as the relevant factors that evaluate the degree of the entrepreneurial intention of university graduates.

\subsection{Career Adaptability}

Career adaptability is defined as an individual's willingness to accept and adjust to the changing nature of the job, work conditions, and environment [61]. It indicates that the readiness to adapt and the ability to manage existing and forthcoming tasks, transitions, and challenges. Career adaptability consists of psychosocial resources, namely career concern, control, curiosity, and confidence that support in managing professional changes and personal distress [57]. It assists in deciding and designing an individual's career based on the goals and choices considering the emotional and environmental dimensions [64]. Career adaptability is also considered as a self-managed skill [64], which is one of the prerequisite attributes for establishing a new venture and continuing its existence for the sustainable development of an enterprise [65]. Previous studies acknowledge career adaptability has a positive association with and a direct influence on entrepreneurial intention [64]. Similarly, it is positively influential in strengthening entrepreneurial development, documented in the literature of this area of study [55]. Hence, extant literature viewed the significance of career adaptability as a dominant factor for the prosperity and long-run success of the new business [65, 41]. 


\subsection{Risk-taking Propensity}

The contemporary importance of the risk-taking propensity of entrepreneurs is widely discussed in entrepreneurship literature [21]. It is considered as one of the elements of psychological capital that leads the entrepreneurs and businesses to reach the desired destination of success [36]. Typically, the risk-taking tendency of entrepreneurs directs them to be willing and skilled in handling uncertain conditions [28]. In general, entrepreneurs are characterized by risk-taking attitude and behavior; thus, they are eager to take risks for the long-term development and existence of the firm [62]. Hence, being able to take and tolerate risk is one of the crucial characteristics of entrepreneurs [70]. Previous studies found a significant positive association between the risk-taking propensity of an entrepreneur and entrepreneurial intention [31]. Acknowledging the existing view, it is observed that the risk-taking tendency contributes immensely to entrepreneurial intentions and actions [23]

\subsection{Institutional Learning}

Institutional learning is considered as the mainstay of student's growth concerning entrepreneurship, which aids in shaping the student's attitude, behavior, and entrepreneurial intention [56]. This indicates that entrepreneurship education gets a positive association with the entrepreneurial intention [26]. Formal entrepreneurship learning becomes a prevalent and widely accepted concept worldwide though there is found a lack of adequate study on it [22]. It plays a key role in creating entrepreneurs and affects entrepreneurial intention by making the students knowledgeable and creative [60]. The individuals having a higher level of institutional learning and education show more interest in getting involved in being self-employed [13]. However, the lack of entrepreneurship education is responsible for hindering entrepreneurship growth, especially in the SME sector [2]. In particular, entrepreneurship educational programs positively influence the entrepreneurs' intention to become self-employed by starting a new business [3]. Therefore, people who have obtained formal education on establishing a new initiative show more interest and willingness to become entrepreneurs [3]. In line with the above, institutional learning helps university graduates to grow as successful entrepreneurs in the years to come by influencing their entrepreneurial tendency $[15,3]$. Thus, many entrepreneurs are inspired and encouraged with significant influence to undertake initiatives of a new venture by taking courses of formal entrepreneurship education [71]. Entrepreneurship education enables the students to learn different branches of required tasks to be performed and show the ways to conduct the jobs efficiently and help further in creating self-efficacy [3]. In this regard, institutions like universities promote entrepreneurship among students by providing required education and training on necessary skills and abilities to develop new businesses, which are essential, to explore the full potential of entrepreneurship growth and to ensure further promotion of this vibrant sector [8].

\subsection{Entrepreneurial Self-efficacy}

Entrepreneurial self-efficacy is defined as the individual's perception of competencies and confidence in conducting tasks to meet the stated goals and objectives [12]. In particular, it is a belief in personal skills that a person can do the job, which has a significant influence on becoming the owner of their own business [18]. In line with this, the degree of self-efficacy is associated with the degree of perceived self-employed intention, which depends on personal traits and environmental dimensions [67]. Entrepreneurial self-efficacy acts as a mediator to represent the relationship between risk-taking propensity and entrepreneurial intention to encourage people to start a new business [71]. Accommodating this well-accepted view, self-efficacy is considered as the core skill that influences entrepreneurial intention [6]. Moreover, entrepreneurial self-efficacy is closely related to the entrepreneurial intention to build an entrepreneurial society $[9,67]$. It can also be best used in deciding and shaping career alternatives $[12,14]$. The self-efficacy of graduates needs to be improved so that they may be capable of handling any uncertain and challenging condition and make strategic decisions to meet the predetermined objectives by overcoming the problems they face [58].

\subsection{Entrepreneurial Intention}

Entrepreneurship is considered as one of the most contributory aspects of economic development in many countries around the world [49]. The central drive of entrepreneurial attitude, action, and behavior refer to the initiative and promise of individuals to become an entrepreneur by starting a new venture [47]. The entrepreneurial intention of university graduates can be defined as every effort they make to start and run their firms [29]. In general, Entrepreneurial intention implies the desire of a person and willingness to undertake a course of action to become self-employed rather than salaried employed or unemployed [51]. Prior studies have explored some factors that influence entrepreneurial intention, and an individual's desire to start an initiative includes the general and entrepreneurial self-efficacy, personal and environmental dimensions [35]. Being self-employed varies depending on culture, origin, situation, and environment, while several individual and contextual factors are significantly associated with the entrepreneurial intention [40]. Therefore, entrepreneurial intention 
occupies a central place in entrepreneurship literature because it works to indicate how much a person is willing and committed to starting a new business [5].

\subsection{Framework and Hypotheses Development}

Based on the existing literature of entrepreneurial intention, this paper draws a few directional hypotheses between the study constructs. The current study's conceptual framework (Figure 1) proposes four exogenous constructs (i.e., career adaptability, risk propensity, institutional learning, and self-efficacy) that directly affect university graduates' entrepreneurial intention. More specifically, the framework contends that career adaptability affects the self-efficacy of graduates. This proposition receives support from previous studies in similar areas [10]. Likewise, risk-taking propensity also influences graduates to develop their self-efficacy. In this regard, previous studies acknowledge that graduates who possess risk-taking propensity have an opportunity to improve their self-efficacy [71]. Furthermore, university graduates consider institutional learning as one of the essential podiums for building their self-efficacy. This proposition also receives support from previous studies [71]. However, the outcome of a recent study differs from this proposition [29]. It is also evident that formal education helps to ensure the lifestyles and working styles of successful entrepreneurs that also help an individual to develop their psychological coping strategies [71]. Hence, in turn, the general self-efficacy of a student leads to be an entrepreneur [12]. Furthermore, many previous studies contend that university graduates having improved general self-efficacy are more willing to be an entrepreneur [10, 71, 29]. Therefore, the above discussions and arguments lead to the following hypotheses:

H1: Career Adaptability has direct and positive effects on self-efficacy.

H2: Risk-taking propensity has direct and positive effects on self-efficacy.

H3: Institutional learning has a direct and positive effect on self-efficacy, and

H4: Self-efficacy has direct and positive effects on entrepreneurial intention.

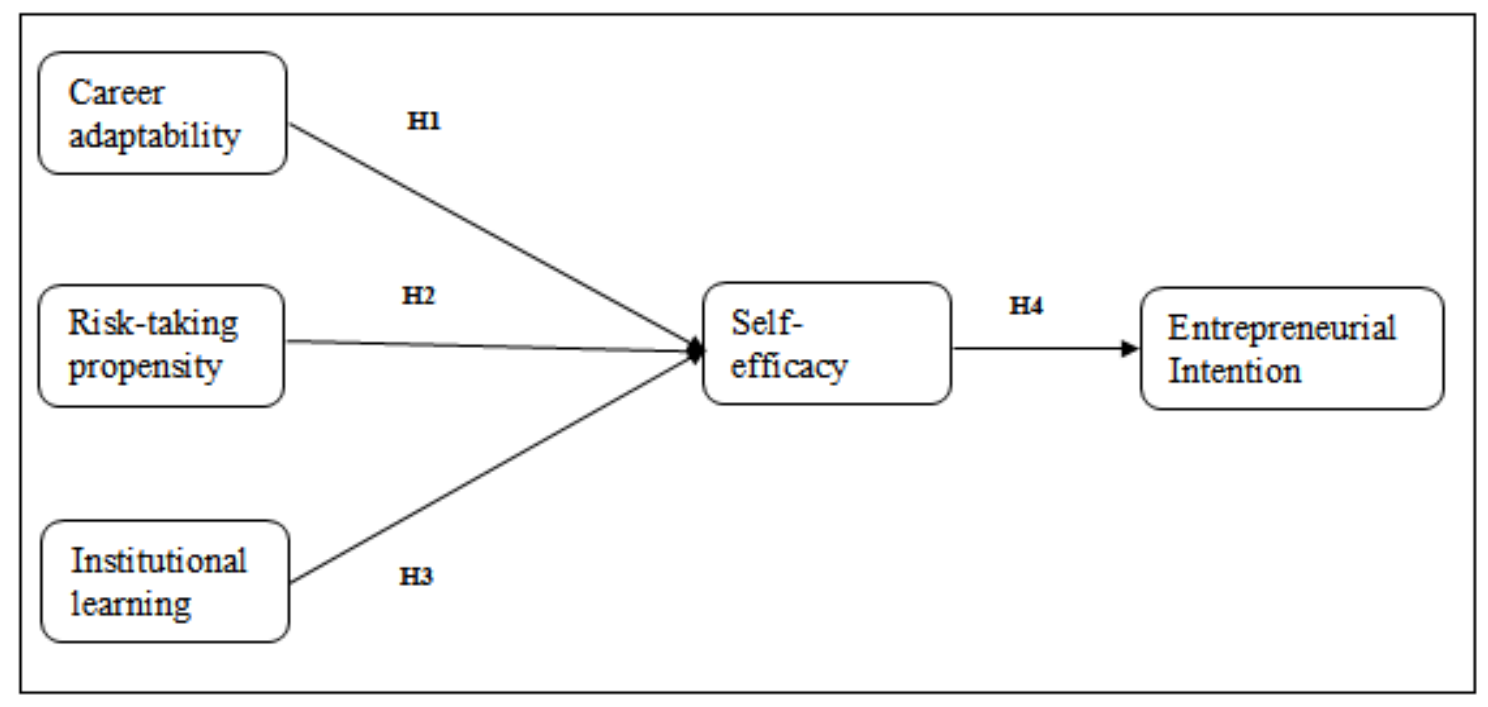

Figure 1. Conceptual Framework 


\section{Research Methods}

\subsection{Measures and Sampling Technique}

A quantitative survey was carried out by collecting data to test the significance of the proposed relations in the conceptual framework. In total, 22 items and five basic demographic questions (e.g., age, gender, marital status, etc.) were used in the survey questionnaire. Specifically, the items that measure the construct of career adaptability were adopted from the study of [10]. The items that measure the constructs of risk-taking propensity, institutional learning, and self-efficacy were adopted from the study of [71]. These items were assessed on a six-point Likert rating scale where $1=$ strongly disagree, and $6=$ strongly agree.

Initially, the graduates were recruited from two different universities (i.e., University of Rajshahi, and Sher-e-Bangla Agricultural University, Dhaka) in Bangladesh, and the study received a total of 242 responses using convenience sampling. 235 usable responses were used for the final analysis, and the rest were discarded from the analysis due to a large proportion of incomplete responses. 175 were university graduates, and the other 60 were job-seekers who have recently completed their graduation from these universities [39, 63]. The sample size used in this study met the minimum sample to perform the data analysis method, i.e., Partial Least Squares-Structural Equation Modeling (PLS-SEM). It is also important to note that participation in this survey was voluntary.

\subsection{Data Analysis Technique and Procedures}

The study employed Partial Least Squares-based Structural Equation Modeling (PLS-SEM) to examine the relationships of the used constructs in the conceptual framework. This analytical technique is more appropriate for exploratory and confirmatory research to investigate the extent of the relationships between the exogenous and endogenous constructs, where independent constructs predict the ultimate dependent construct [32, 54]. In assessing the conceptual framework in the PLS-SEM procedure, this study firstly performed the validity and reliability by examining factor loading, cross-loading, average variance extracted (AVE), composite reliability (CR), and Cronbach's alpha. Next, discriminant validity was tested using Fornell and Larcker's (1981) criteria, which is traditionally used in business research. These were assessed by using different suggested threshold values [20, 27, 33]. Lastly, a bootstrapping procedure was performed to test the proposed path relationships of the hypotheses.

\section{Results}

\subsection{Demographic Results}

The sample (University graduates) was obtained by using a questionnaire survey. Demographic variables, namely age, gender, marital status, occupation, and income, were considered as the basic profile of the respondents. Results illustrate (also see Table 1) that the majority of respondent's age was in the range of 21-25 (75.3\%), followed by $26-30(12.8 \%)$ and $18-20(11.9 \%)$. In terms of gender and marital status, many respondents were men $(59.6 \%)$ and single $(79.60 \%)$, and the rest are women and married. Concerning the education level, a significant proportion is graduated $(64.2 \%)$, and the rest were post-graduates $(35.8 \%)$. Lastly, in terms of the monthly income of the respondents or their parents, $33.6 \%$ of the respondents earned less than Tk. 20001-30000, followed by Tk. below 20000 (22.1\%), and Tk. 30001-40000 (21.3\%).

Table 1. Respondents' Information

\begin{tabular}{cccccc}
\hline Characteristics & $\mathbf{( N = 2 3 5 )}$ & $\mathbf{( \% )}$ & Characteristics & $\mathbf{( N = 2 3 5 )}$ & $\mathbf{( \% )}$ \\
\hline Age: & & Education: & \\
\hline $18-20$ years & 28 & 11.9 & Graduation & 151 & 64.2 \\
\hline $21-25$ years & 177 & 75.3 & Post-graduation & 84 & 35.8 \\
\hline above 30 & - & - & Income: & 22.1 \\
\hline Gender: & & Below 20000 & 52 & 33.6 \\
\hline Male & 140 & 59.6 & $20001-30000$ & 79 & 21.3 \\
\hline Female & 95 & 40.4 & $30001-40000$ & 50 & 8.1 \\
\hline Marital Status: & & $40001-50000$ & 19 & 6.8 \\
\hline Single & 187 & 79.6 & $50001-60000$ & 16 & 8.1 \\
\hline Married & 48 & 20.4 & Above 60000 & 19 & \\
\hline
\end{tabular}

Note: $\mathrm{N}=$ number of respondents, $\%=$ valid percentage. 


\subsection{Assessment of Measurement Model}

The measurement model performs factor loading, Cronbach's Alpha, composite reliability (CR), and average variance extracted (AVE) to establish the convergent validity [27]. Table 2 demonstrates that loading values of all items that exceeded the suggested threshold value of $0.5[34,68]$, and CR values of the study constructs exceeded the standard critical level of the recommended value of 0.708 [32]. Lastly, the study found that it is greater than the suggested value of 0.5 of the AVE of the study constructs, which was adequate for convergent validity $[11,27]$. Therefore, all the three requisites of the convergent validity of the reflective model were met.

Discriminant validity of the study model was further assessed by the test recommended by Fornell and Larcker (1981) criteria. It suggests that the square root of the AVE should exceed the correlation values between the study constructs. Discriminant validity confirms the extent to which indicators differentiate the study constructs. The notion of assessing discriminant validity is the constructs used in the study should be distinct from one another [42]. However, Table 3 explains that the square roots of the AVEs were more extensive than the correlation values for the individual constructs pairing. Thus, results adequately show that discriminant validity was met.

Table 2. Results of the measurement model

\begin{tabular}{|c|c|c|}
\hline Item Code & Item Description & Loadings \\
\hline CA & Career Adaptability $(\mathrm{CA}=0.80, \mathrm{CR}=0.88, \mathrm{AVE}=0.72)$ & \\
\hline CA1 & Concern about career adaptability & 0.85 \\
\hline CA2 & Curiosity about career adaptability & 0.87 \\
\hline CA3 & Confidence about career adaptability & 0.82 \\
\hline $\mathbf{R P}$ & Risk-taking Propensity $(\mathrm{CA}=0.81, \mathrm{CR}=0.90, \mathrm{AVE}=0.84)$ & \\
\hline RP1 & Enjoy the excitement of uncertainty \& risk & 0.92 \\
\hline $\mathrm{RP} 2$ & Willing to take the risk if enough possible rewards & 0.93 \\
\hline RP3 & Willing to take financial risk in an entrepreneurial activity & 0.71 \\
\hline IL & Institutional Learning (IL) (CA=0.87, CR=0.91, AVE=0.72) & \\
\hline IL1 & Perceive IL as opportunity recognition & 0.83 \\
\hline IL2 & Perceived IL as opportunity evaluation & 0.88 \\
\hline IL3 & Perceived IL as starting a business & 0.85 \\
\hline IL4 & Perceived IL as corporate entrepreneurship & 0.83 \\
\hline SE & Self-efficacy $(\mathrm{CA}=0.91, \mathrm{CR}=0.93, \mathrm{AVE}=0.65)$ & \\
\hline SE1 & Solve challenging problems if try hard & 0.80 \\
\hline SE2 & If someone opposes me, I find the means \& ways to get what I want & 0.81 \\
\hline SE3 & Easy for me to stick to my aim and accomplish my goals & 0.78 \\
\hline SE4 & Confident to deal efficiently with unexpected events & 0.80 \\
\hline SE5 & Solve most problems if invest the necessary effort & 0.82 \\
\hline SE6 & Remain calm when facing difficulties because I rely on my coping abilities & 0.82 \\
\hline SE7 & If in trouble, I usually think of a solution & 0.80 \\
\hline EI & Entrepreneurial Intention $(\mathrm{CA}=0.92, \mathrm{CR}=0.94, \mathrm{AVE}=0.76)$ & \\
\hline EI1 & Seriously thinking of starting a firm & 0.90 \\
\hline EI2 & Provide every effort to start and run my firm & 0.89 \\
\hline $\mathrm{EI} 3$ & Ready to do anything to be an entrepreneur & 0.87 \\
\hline EI4 & Professional goal is to become an entrepreneur & 0.86 \\
\hline EI5 & Determine to create a firm in the future & 0.85 \\
\hline
\end{tabular}

Note: $\mathrm{CA}=$ Cronbach's alpha, $\mathrm{CR}=$ composite reliability, and $\mathrm{AVE}=$ average variance extracted.

Table 3. The square root of the AVE and correlation of coefficient

\begin{tabular}{lccccc}
\hline Fornell and Larcker Criterion & & & & \\
\hline & 1 & 2 & 3 & 5 \\
\hline 1. Career Adaptability & $\mathbf{0 . 8 5}$ & & & & \\
\hline 2. Entrepreneurial Intention & 0.66 & $\mathbf{0 . 8 7}$ & & & \\
\hline 3. Institutional Learning & 0.70 & 0.76 & $\mathbf{0 . 8 5}$ & & \\
\hline 4. Risk-taking Propensity & 0.61 & 0.70 & 0.72 & $\mathbf{0 . 9 0}$ & \\
\hline 5. Self-efficacy & 0.76 & 0.75 & 0.81 & 0.71 & $\mathbf{0 . 8 0}$ \\
\hline
\end{tabular}

Note: Bold diagonal values represent the square root of the AVE, and the off-diagonal value represents the correlation of coefficient. 


\subsection{Assessment of Structural Model}

In the structural model, the bootstrapping procedure was used to test the path relations. This analytical technique ensures the exactness and significance of the path relation between the study constructs [32]. In this case, a total of 5,000 subsamples were taken from the original sample. The bootstrapping procedure (Table 4) illustrates that the direct effects of CA, RP, and IL on SE, and the direct effect of SE on EI were positive and significant. Therefore, hypotheses $\mathrm{H} 1, \mathrm{H} 2, \mathrm{H} 3$, and $\mathrm{H} 4$ were supported. In particular, Table 4 depicts that career adaptability has a significant positive influence on entrepreneurial self-efficacy ( $\beta=0.35$ and $t=5.80$ ). Risk propensity also plays a significant positive role in developing the entrepreneurial self-efficacy of a business graduate $(\beta=$ 0.14 and $t=3.05$ ). Likewise, the institutional learning of a university graduate helps build his/her self-efficacy $(\beta=$ 0.46 and $t=7.46$ ), and the overall self-efficacy of a graduate strongly leads to entrepreneurial intention $(\beta=$ 0.75 and $t=20.11$ ). Therefore, hypotheses $\mathrm{H} 1, \mathrm{H} 2, \mathrm{H} 3$, and H4 were supported.

Table 4. Results of the Structural Model

\begin{tabular}{ccccl}
\hline Hypotheses & $\begin{array}{c}\text { Path } \\
\text { relationship }\end{array}$ & $\begin{array}{c}\text { Coefficient } \\
(\boldsymbol{\beta})\end{array}$ & $\begin{array}{c}\mathbf{T} \\
\text { Statistics }\end{array}$ & Decisions \\
\hline $\mathrm{H}_{1}$ & CA -> SE & 0.35 & $5.80^{* *}$ & Supported \\
\hline $\mathrm{H}_{2}$ & $\mathrm{RP}$ - > SE & 0.14 & $3.05^{* *}$ & Supported \\
\hline $\mathrm{H}_{3}$ & IL -> SE & 0.46 & $7.46^{* *}$ & Supported \\
\hline $\mathrm{H}_{4}$ & SE -> EI & 0.75 & $20.11^{* *}$ & Supported \\
\hline
\end{tabular}

Note: $* * \mathrm{p}<0.01, * \mathrm{p}<0.05$ (two-tailed). $\mathrm{CA}=$ Career adaptability, RP= Risk-taking propensity, $\mathrm{IL}=$ Institutional learning, $\mathrm{SE}=$ Self-efficacy, and $\mathrm{EI}=$ Entrepreneurial intention.

\section{Discussions and Implications}

This study discusses how career adaptability, risk-taking propensity, and institutional learning contribute to building university graduates' self-efficacy; in turn, self-efficacy leads towards their entrepreneurship intention. This study examined the entrepreneurial intention of university graduates in the context of Bangladesh. Selected numbers of latent constructs have been considered to measure the interrelationships of the used constructs and their effects on the entrepreneurial intention of university graduates. The estimation presents that the proposed four hypotheses of this study have been supported. In particular, career adaptability has a direct and positive effect on self-efficacy (H1), which indicates that an individual's ability to assess and analyze the environment to cope with the changes influence the sense of confidence and competencies positively. Whenever anyone becomes skilled in adopting in any changing situation and can do his tasks, he/she becomes confident about his/her capabilities. Likewise, risk-taking propensity also directly influences self-efficacy $(\mathrm{H} 2)$. This finding is also similar to the existing literature [71, 17], and this result differs from some other studies [44, 24]. It reveals that the tendency to take the risks of building a useful account for working in an uncertain environment increases trust and confidence in one's capabilities and performance.

Similarly, Institutional learning has a direct and positive impact on self-efficacy. Existing studies support this finding $[56,1,29,71,3]$ and contradict other studies [52]. The finding explores that institutional learning puts a quality on an individual's attitude and behavior and makes them knowledgeable and creative to conduct all essential jobs to start a new venture and thus assists in developing and building self-efficacy. Finally, self-efficacy, in turn, has a direct and positive effect on entrepreneurial intention (H4). This result is supported by extant literature $[45,9,64,29,10,56]$. The work reveals that one's belief and trust in his capabilities and performance positively motivate him to become an entrepreneur. Therefore, the intention of university graduates to be entrepreneurs is significantly influenced by the student's self-efficacy. These findings have some invaluable theoretical and practical implications in the entrepreneurship literature.

\subsection{Theoretical Implications}

The study offers significant theoretical implications and valuable insights into the field of entrepreneurship. This paper pays attention to an improved understanding of the instruments that strengthen entrepreneurial intention among university graduates. More precisely, efforts were made to examine entrepreneurial intention among university graduates considering the effect of career adaptability, risk-taking propensity, institutional learning, and self-efficacy. The concept of career adaptability plays a significantly positive role in entrepreneurial self-efficacy. Hence, empirical support for the study was provided by exploring a relatively high association, and the interrelationship between these two constructs [10].

Similarly, a risk-taking attitude also plays a significantly positive role in developing the entrepreneurial self-efficacy of the graduates. Those who elicit a higher risk-taking propensity can best fit themselves to be more capable of performing entrepreneurial tasks [71]. Likewise, formal academic programs help university graduates to develop their self-efficacy. Individuals who get opportunities to study at university have higher levels of entrepreneurial self-efficacy [71]. Overall, self-efficacy importantly directs and motivates a graduate to become an entrepreneur [18, 67]. However, some researchers observe that the development of entrepreneurial intention requires multiple ranges of variables, not only self-efficacy. The study also extends the role of the Theory of Planned Behavior in the entrepreneurship literature. Extant literature primarily provides an overview and understanding, in general, of the 
influential factors of entrepreneurial intention. However, this study concentrates on young entrepreneurship, namely university graduates of different universities in Bangladesh.

\subsection{Practical Implications}

This study aims to investigate university graduates' entrepreneurial intention by testing some selected constructs that might produce the following valuable practical implications:

Firstly, the findings of the study may aid potential entrepreneurs, especially university graduates, in deciding how to start and run a successful business. It will contribute to developing their attitude, behavior, and skills by offering formal entrepreneurship education to begin a challenging journey in the business domain. Entrepreneurship education assists potential entrepreneurs in finding opportunities, managing resources, and leading teams that may stimulate entrepreneurs' intention to grow as successful entrepreneurs. Secondly, the educators and academicians of universities and institutes may get some helpful insights and information. Thus, they may invest their efforts in designing courses, curricula, and programs that cater to the modern and updated needs of the graduates and enable the students to be prepared for the commencement of the new business initiative. Thirdly, the findings of this paper may act as a guide for policy-makers and relevant authorities. They can develop special entrepreneurship programs for creative and dynamic university graduates as part of policy implications. This initiative would encourage graduates to carry out their innovative business ideas.

\section{Conclusions and Future Research}

Many countries are now struggling to generate enough employment opportunities, and consequently, a growing portion of university graduates are facing difficulties finding jobs in their specialized area and significant $[43,29]$. In addressing this problem, entrepreneurship can be the best and fancy solution, which may reduce the curse of unemployment and accelerate economic growth to reach in the new economic height [43]. In this regard, knowledge, and understanding about the influential factors and determinants of creating entrepreneurs are essential, specifically building entrepreneurial intentions among young adults [43]. Therefore, the current research attempted to investigate the entrepreneurial intention of university graduates in the context of Bangladesh. The conceptual framework was formulated, and accordingly, set hypotheses were developed based on the theory of planned behavior (TPB). The original model of entrepreneurial intention has been supported and extended in this study by examining five latent constructs. The findings of this study significantly contribute to the entrepreneurship literature in developing entrepreneurial intention among young adults, particularly university graduates. However, the present study has a common limitation, which serves as the future research directions to be further researched. Firstly, the study was confined to two public universities that might limit the generalizability of the results. Thus, considering more graduates from different universities may generate more valid and accurate results.

\section{REFERENCES}

[1] Adekiya, A., and F. Ibrahim. 2016. "Entrepreneurship Intention among Students. The Antecedent Role of Culture and Entrepreneurship Training and Development." The International Journal of Management Education 14 (2): 116-132.

[2] Ahmad, S. Z., \& Xavier, S. R. (2012). Entrepreneurial environments and growth: evidence from Malaysia GEM data. Journal of Chinese Entrepreneurship.

[3] Ahmed, T., Chandran, V. G. R., Klobas, J. E., Linan, F., \& Kokkalis, P. (2020). Entrepreneurship education programs: How learning, inspiration, and resources affect intentions for new venture creation in a developing economy. The International Journal of Management Education, 18(1), 100327.

[4] Ajzen, I. (1985). From intentions to actions: A theory of planned behavior. Action control (pp. 11-39). Springer, Berlin, Heidelberg.

[5] Ajzen, I. (1991). The theory of planned behavior. Organizational behavior and human decision processes, 50(2), 179-211.

[6] Ajzen, I. (2002). Perceived behavioral control, self efficacy, locus of control, and the theory of planned behavior 1. Journal of applied social psychology, 32(4), 665-683.

[7] Alim, M. A., Emon, M. A. I., \& Biswas, R. (2018). SMEs' Wasted Opportunity to Enhance Economic Development of Bangladesh. Journal of the Institute of Bangladesh Studies, 41, 67-80.

[8] Anjum, T., Ramani Bai, V., \& Phung, S. P. (2020). Moderating Role of University Support on the relationship between Effective Entrepreneurship Education and Entrepreneurial Intention.

[9] Arenius, P., \& Minniti, M. (2005). Perceptual variables and nascent entrepreneurship. Small business economics, 24(3), 233-247.

[10] Atitsogbe, K. A., Mama, N. P., Sovet, L., Pari, P., \& Rossier, J. (2019). Perceived employability and entrepreneurial intentions across university students and job seekers in Togo: The effect of career adaptability and self-efficacy. Frontiers in psychology, 10, 180.

[11] Bagozzi, R. P., \& Yi, Y. (1988). On the evaluation of 
structural equation models. Journal of the academy of marketing science, 16(1), 74-94.

[12] Bandura, A. (1977). Self-efficacy: toward a unifying theory of behavioral change. Psychological Review, 84(2), 191.

[13] Bates, T. (1995). Self-employment entry across industry groups. Journal of business venturing, 10(2), 143-156.

[14] Betz, N. E., \& Hackett, G. (2006). Career self-efficacy theory: Back to the future. Journal of career assessment, 14(1), 3-11.

[15] Bischoff, K., Volkmann, C. K., \& Audretsch, D. B. (2018). Stakeholder collaboration in entrepreneurship education: An analysis of the entrepreneurial ecosystems of European higher educational institutions. The Journal of Technology Transfer, 43(1), 20-46.

[16] Blustein, D. L., Chaves, A. P., Diemer, M. A., Gallagher, L. A., Marshall, K. G., Sirin, S., \& Bhati, K. S. (2002). Voices of the forgotten half: The role of social class in the school-to-work transition. Journal of Counseling Psychology, 49(3), 311.

[17] Bolton, D. L., \& Lane, M. D. (2012). Individual entrepreneurial orientation: Development of a measurement instrument. Education+ Training.

[18] Boyd, N. G., \& Vozikis, G. S. (1994). The influence of self-efficacy on the development of entrepreneurial intentions and actions. Entrepreneurship theory and practice, 18(4), 63-77.

[19] Brannback, M., Carsrud, A., Elfving, J., Kickul, J., \& Krueger, N. (2006, July). Why replicate entrepreneurial intentionality studies? Prospects, perils, and academic reality. In SMU edge conference, Singapore.

[20] Byrne, B. M. (2010). Multivariate applications series. Structural equation modeling with AMOS: Basic concepts, applications, and programming (2nd ed.). New York: Routledge/Taylor \& Francis Group.

[21] Caliendo, M., Fossen, F. M., \& Kritikos, A. S. (2009). Risk attitudes of nascent entrepreneurs-new evidence from an experimentally validated survey. Small business economics, $32(2), 153-167$.

[22] Cao, T. N., \& Huang, S. (2020). A systematic literature review on Engineering Entrepreneurship Education Learning Outcomes and Assessment Tools. Proceedings of the Canadian Engineering Education Association (CEEA).

[23] Chipeta, E. M., \& Surujlal, J. (2017). Influence of attitude, risk taking propensity and proactive personality on social entrepreneurship intentions. Polish Journal of Management Studies, 15.

[24] Ekpe, I., \& Mat, N. (2012). The moderating effect of social environment on the relationship between entrepreneurial orientation and entrepreneurial intentions of female students at Nigerian universities. International Journal of Management Sciences and Business, 1(4).

[25] Fellnhofer, K., \& Kraus, S. (2015). Examining attitudes towards entrepreneurship education: a comparative analysis among experts. International Journal of Entrepreneurial Venturing, 7(4), 396-411.

[26] Fitzsimmons, J. R., \& Douglas, E. J. (2011). Interaction between feasibility and desirability in the formation of entrepreneurial intentions. Journal of business venturing, 26(4), 431-440.

[27] Fornell, C., \& Larcker, D. F. (1981). Evaluating structural equation models with unobservable variables and measurement error. Journal of Marketing Research, 18(1), $39-50$.

[28] Frank, H., Korunka, C., \& Lueger, M. (2002). The significance of personality in business startup intentions, startup realization and business success. In Conference Europeenne d'ete.

[29] Fragoso, R., Rocha-Junior, W., \& Xavier, A. (2020). Determinant factors of entrepreneurial intention among university students in Brazil and Portugal. Journal of Small Business \& Entrepreneurship, 32(1), 33-57.

[30] Glinskiene, R., \& Petuskiene, E. (2011). The Incentive of Entrepreneurship as the force of Country's Economic Development. Ekonomika ir vadyba, (16), 179-188.

[31] Gurel, E., Altinay, L., \& Daniele, R. (2010). Tourism students' entrepreneurial intentions. Annals of Tourism Research, 37(3), 646-669.

[32] Hair Jr, J. F., Hult, G. T. M., Ringle, C., \& Sarstedt, M. (2017). A primer on partial least squares structural equation modeling (PLS-SEM). Sage publications.

[33] Hair, J. F., Anderson, R. E., Babin, B. J., \& Black, W. C. (2010). Multivariate data analysis: A global perspective (Vol. 7).

[34] Hair, J. F., Ringle, C. M., \& Sarstedt, M. (2011). PLS-SEM: Indeed a silver bullet. Journal of Marketing Theory and Practice, 19(2), 139-152.

[35] Hance, J., Howell, R., Litzky, B. E., Winkel, D., \& Vanevenhoven, J. (2019). Entrepreneurial Influences: Comparing Entrepreneurial Intention in the United States and Portugal. In United States Association for Small Business and Entrepreneurship. Conference Proceedings (No. 1, pp. 83-93). United States Association for Small Business and Entrepreneurship.

[36] Herath, H. M. T. S. (2014). Conceptualizing the role of opportunity recognition in entrepreneurial career success. International Journal of Scientific Research and Innovative Technology, 1(3), 73-82.

[37] Hisrich, R., Langan-Fox, J., \& Grant, S. (2007). Entrepreneurship research and practice: a call to action for psychology. American psychologist, 62(6), 575.

[38] Hisrich, R. D., Peters, M. P., \& Shepherd, D. A. (2013). Entrepreneurship (9th edn).

[39] Hoyle, R. H. (1995). Structural equation modeling: Concepts, issues, and applications. Sage.

[40] Ismail, M., Khalid, S. A., Othman, M., Jusoff, H. K., Rahman, N. A., Kassim, K. M., \& Zain, R. S. (2009). Entrepreneurial intention among Malaysian undergraduates. International Journal of Business and Management, 4(10), 54-60.

[41] Kanten, S. (2012). Kariyer uyum yetenekleri olçegi: geçerlilik ve guvenilirlik çalişmasi. Journal of Suleyman Demirel University Institute of Social Sciences Year, 2(16), 191-205. 
[42] Kassarjian, H. H. (1977). Content analysis in consumer research. Journal of consumer research, 4(1), 8-18.

[43] Koe, W. L. (2016). The relationship between Individual Entrepreneurial Orientation (IEO) and entrepreneurial intention. Journal of Global Entrepreneurship Research, 6(1), 13.

[44] Koe, W. L., Sa'ari, J. R., Majid, I. A., \& Ismail, K. (2012). Determinants of entrepreneurial intention among millennial generation. Procedia-Social and Behavioral Sciences, 40, 197-208.

[45] Kristiansen, S., \& Indarti, N. (2004). Entrepreneurial intention among Indonesian and Norwegian students. Journal of enterprising culture, 12(01), 55-78.

[46] Krueger Jr, N. F., Reilly, M. D., \& Carsrud, A. L. (2000). Competing models of entrepreneurial intentions. Journal of business venturing, 15(5-6), 411-432.

[47] Krueger, N. (1993). The impact of prior entrepreneurial exposure on perceptions of new venture feasibility and desirability. Entrepreneurship theory and practice, 18(1), 5-21.

[48] Krueger Jr, N. F., \& Brazeal, D. V. (1994). Entrepreneurial potential and potential entrepreneurs. Entrepreneurship theory and practice, 18(3), 91-104.

[49] Linan, F., Rodríguez-Cohard, J. C., \& Rueda-Cantuche, J. M. (2011). Factors affecting entrepreneurial intention levels: a role for education. International entrepreneurship and management Journal, 7(2), 195-218.

[50] Ngugi, J. K., Gakure, R. W., Waithaka, S. M., \& Kiwara, A. N. (2012). Application of Shapero's model in explaining entrepreneurial intentions among university students in Kenya. International Journal of Business and Social Research (IJBSR), 2(4), 125-148.

[51] Ojiaku, O. C., Nkamnebe, A. D., \& Nwaizugbo, I. C. (2018). Determinants of entrepreneurial intentions among young graduates: perspectives of push-pull-mooring model. Journal of Global Entrepreneurship Research, 8(1), 24.

[52] Peng, Z., Lu, G., \& Kang, H. (2013). Entrepreneurial intentions and its influencing factors: A survey of the university students in Xi'an China. Creative education, 3(08), 95.

[53] Peterman, N. E., \& Kennedy, J. (2003). Enterprise education: Influencing students' perceptions of entrepreneurship. Entrepreneurship theory and practice, $28(2), 129-144$.

[54] Ringle, C., Wende, S., \& Becker, J. (2015). SmartPLS 3. Bonningstedt: SmartPLS.

[55] Rudolph, C. W., Lavigne, K. N., \& Zacher, H. (2017). Career adaptability: A meta-analysis of relationships with measures of adaptivity, adapting responses, and adaptation results. Journal of Vocational Behavior, 98, 17-34.

[56] Saeed, S., Yousafzai, S. Y., Yani - De - Soriano, M., \& Muffatto, M. (2015). The role of perceived university support in the formation of students' entrepreneurial intention. Journal of small business management, 53(4), $1127-1145$

[57] Savickas, M. L., \& Porfeli, E. J. (2012). Career Adapt-Abilities Scale: Construction, reliability, and measurement equivalence across 13 countries. Journal of vocational behavior, 80(3), 661-673.Shane, S., Locke, E. A., \& Collins, C. J. (2003). Entrepreneurial motivation. Human resource management review, 13(2), 257-279.

[58] Shirokova, G., Osiyevskyy, O., \& Bogatyreva, K. (2016). Exploring the intention-behavior link in student entrepreneurship: Moderating effects of individual and environmental characteristics. European Management Journal, 34(4), 386-399.

[59] Solomon, G., Hamidi, D. Y., Wennberg, K., \& Berglund, H. (2008). Creativity in entrepreneurship education. Journal of small business and enterprise development.

[60] Super, D. E., \& Knasel, E. G. (1981). Career development in adulthood: Some theoretical problems and a possible solution. British journal of guidance and counselling, 9(2), 194-201.

[61] Syed, A. M., Alaraifi, A., \& Ahmad, S. (2019). Entrepreneurs in Saudi Arabia: Risk Attitude and Predisposition towards Risk Management. Journal of Entrepreneurship Education, 22(4), 1-18.

[62] Tabachnick, B. G., Fidell, L. S., \& Ullman, J. B. (2007) Using multivariate statistics (Vol. 5, pp. 481-498). Boston, MA: Pearson.

[63] Tolentino, L. R., Sedoglavich, V., Lu, V. N., Garcia, P. R. J. M., \& Restubog, S. L. D. (2014). The role of career adaptability in predicting entrepreneurial intentions: A moderated mediation model. Journal of Vocational Behavior, 85(3), 403-412.

[64] Umukoro, O. S., \& Okurame, D. E. (2018). Role of mentoring in career adaptability and ambiguity tolerance of potential Nigerian entrepreneurs: the moderating effect of age. Journal of Global Entrepreneurship Research, 8(1), $1-13$.

[65] Veysi, M., Veisi, K., Hashemi, S., \& Khoshbakht, F. (2015). Analyse of factors affecting the development of an entrepreneurial intention among fresh graduated students in Islamic Azad University, Sahneh, Iran. Indian Journal of Fundamental and Applied Life Sciences, 5, 397-410.

[66] Wang, J. H., Chang, C. C., Yao, S. N., \& Liang, C. (2016). The contribution of self-efficacy to the relationship between personality traits and entrepreneurial intention. Higher Education, 72(2), 209-224.

[67] Wong, K. K.-K. (2013). Partial Least Squares Structural Equation Modeling (PLS-SEM) Techniques Using SmartPLS. Marketing Bulletin, 24(1), 1-32.

[68] Wu, J. (2010). The impact of corporate supplier diversity programs on corporate purchasers' intention to purchase from women-owned enterprises: An empirical test. Business \& Society, 49(2), 359-380.

[69] Yordanova, D. I., \& Alexandrova-Boshnakova, M. I. (2011). Gender effects on risk - taking of entrepreneurs: evidence from Bulgaria. International Journal of Entrepreneurial Behavior \& Research

[70] Zhao, H., Seibert, S. E., \& Hills, G. E. (2005). The mediating role of self-efficacy in the development of entrepreneurial intentions. Journal of applied psychology, 90(6), 1265. 